by experiments in which the brains of Toxoplasma dye-testnegative mice were fed to an S.P.F. cat. No cysts appeared in the faeces (Hutchison, Dunachie, Siim, and Work, unpublished work). The coccidian nature of the life cycle of $T$. gondii, which has now been unfolded, did not come as a surprise, in view of the coccidian characteristics of the oocyst which had already been observed. In addition to its morphological and developmental similarities, this oocyst of Toxoplasma resembled those of the coccidia in its ability to withstand chemical action (Hutchison et al., 1969).

It was disappointing to find only a single schizont in S.P.F. 3 , especially since such large numbers of oocysts had been produced. It must be conceded, however, that only a relatively small region of the cat's intestine was examined. The entire intestine of this cat, however, has been fixed, and we feel that further investigations of other regions may be worth while. So far as we were concerned, the importance of this single schizont was that we were given an indication of what to search for. In addition, we were also convinced that our staining procedures were adequate.

In cat S.P.F. 2 the infections of the intestinal epithelial cells were profuse and were in the posterior region (portions 5,6 , and 7) of the small intestine. It must be pointed out that we are dealing in this instance with a single cat and that many more cats must be examined before the sites of schizogony and gametogony can be established with certainty. In this preliminary investigation we obtained the impression that most schizogonic cycles were occurring in a portion of the gut anterior to that containing the gametogonic stages.

Our findings certainly resolve some of the problems of the taxonomist with regard to the classification of $T$. gondii. This organism has been considered to be a member of the class Toxoplasmea within the Subphylum Sporozoa. Now that schizogonic and gametogonic processes identical with those of the coccidians have been described for Toxoplasma there seems to be good reason to classify this organism under the order Eucoccidia, suborder Eimeriina. The possibility that the disease of toxoplasmosis might now be referred to as coccidiosis is an interesting but less important outcome of this work.

We are grateful to Professor P. C. C. Garnham for advice and encouragement. We are also pleased to acknowledge technical assistance from Mr. Denis Dougherty. Work at Strathclyde University is supported in part by grants and materials from the Medical Research Council, the Wellcome Trust, and the World Health Organization. Work at the Department of Toxoplasmosis and Viral Diseases, Statens Seruminstitut, Copenhagen, is aided in part by grants from the King Christian $X$ Foundation, the U.S. Public Health Service, Research Grant Division (Ai 01741), Bethesda, Md., the World Health Organization, and Cold Stores Foundation.

\section{REFERENCES}

Dubey, J. P. (1968). Fournal of Protozoology, 15, 773

Frenkel, J. K., Dubey, J. P., and Miller, N. L. (1969). Science, 164, 432.

Hutchison, W M. (1965). Nature, 206, 961.

Hutchison, W. M. (1967). Transactions of the Royal Society of Tropical Medicine and Hygiene, 61, 80.

Hutchison, W. M., Dunachie, J. F., and Work, K. (1968). Acta Pathologica et Microbiologica Scandinavica, 74, 462.

Hutchison, W. M., Dunachie, J. F., and Work, K. (1969). In Nippostrongylus and Toxoplasma, edited by A. E. R. Taylor, p. 51. Oxford, Blackwell Scientific Publications. Symposium of the British Society for Parasitology, 7, 51.

Hutchison, W. M., and Work, K. (1969b). New Scientist, 42, 464

Hutchison, W. M., and Work, K. (1969a). Acta Pathologica et Microbiologica Scandinavica, 77, 275.

Jacobs, L. (1967). Advances in Parasitology, 5, 1.

Sheffield, H. G., and Melton, M. L. (1969). Science, 164, 431

Sheffield, H. G., and Melton, M. L. (1969). Science, 164, 431.
Siim, J. Chr., Hutchison, W. M., and Work, K. (1969). Acta Pathologica et Microbiologica Scandinavica, 77, 756.

Work, K., and Hutchison, W. M., (1969a). Acta Pathologica et Microbiologica Scandinavica, 75, 191.

Work, K., and Hutchison, W. M. (1969b). Acta Pathologica et Microbiologica Scandinavica, 77, 414.
British Medical fournal, 1970, 1, 144-147

Gummary: In a survey in the Exeter area 139 patients $\checkmark$ with some degrees of abnormal atrioventricular conduction were notified by 282 family doctors. Per 100,000 of the population the prevalence of seconddegree and third-degree heart block was estimated to be 17.3, of complete block past or present 15.6, and of complete block at the time of survey 13.1. Heart block was commoner in men than women, the sex ratio being 1.4 to 1; its prevalence increased steeply with age, and the morbidity rate was less than that reported by others. If the morbidity figures quoted in this survey are representative of the general population, it reaffirms the policy that pacemakers should be recommended for selected patients only.

\section{Introduction}

The use of artificial cardiac pacemakers is now a practical long-term treatment for the patient with heart block, and the organization of a pacemaker service requires knowledge of the prevalence and (and incidence) of this condition. As Siddons and Sowton (1967) pointed out, however, statistics of the prevalence and incidence of heart block in the general population are very approximate, since they are based on the number of patients attending hospital departments. The aim of this study was to carry out a more accurate survey of patients with heart block by a direct approach to the family doctor. This preliminary report describes the prevalence of the condition.

\section{Population and Plan of Study}

Letters were sent to 290 family doctors practising in the Exeter clinical area asking for details of any patients with heart block or bradycardia (pulse rates less than 56 beats per minute). If a reply to the first letter was not received, further inquiries were made, up to a total of three letters. The date of the family doctor's initial reply was taken as the date of survey of his practice and patients diagnosed subsequently were not included. All notified cases were investigated and, where available, previous hospital records and cardiograms obtained. Unless preliminary inquiry indicated that atrioventricular conduction was normal, the patients were seen by a member of the cardiac department, provided that both the family doctor and the patient agreed to the examination. In addition to cases notified by the family doctors patients were studied from two other sources: (1) those known to have heart block who were attending the outpatient department of the Royal Devon and Exeter Hospital and whose family doctors practised within the 
area of the survey, and (2) those recorded as having heart block in the Exeter Morbidity Survey of 1966-7, covering a population of 69,000 (Ashford and Pearson 1968). The total number of patients on the executive council lists for the 290 doctors in the survey area was 581,000 . The population of this area according to the 1966 sample census was 578,000 .

The patients were seen in the cardiac department if they were able to make the journey into Exeter, otherwise they were visited in their homes. Specific questions were asked concerning drug therapy and past history of cardiac infarction, pericarditis, rheumatic fever, and diphtheria. The particular symptoms sought were syncope, dizzy attacks, angina of effort, and breathlessness on exertion. A routine physical examination was carried out to check the presence or absence of congenital or acquired heart disease, and a count was taken of the heart rate at rest and after mild exertion. A 12-lead electrocardiogram (E.C.G.) was recorded, including a 3-ft. (0.9-m.) continuous strip of lead II, with a Cambridge Transrite 111A machine. If there was any uncertainty concerning the type of conduction defect further records were taken with a fourchannel Mingograph Recorder.

\section{Criteria for Admission to Survey}

Patients were admitted to the study if there was electrocardiographic evidence of second- or third-degree heart block in the absence of treatment with digitalis, propranolol, or related drugs. Those in the acute phase of rheumatic fever or cardiac infarction (infarction within the preceding month) were excluded.

The patients were classified according to the cardiogram at the time of our examination into the following groups: (1) complete heart block (third degree-stable and unstable), (2) partial heart block (second degree-stable and unstable), and (3) normal conduction but previous E.C.G. changes compatible with admission to the trial. The subdivision of groups 1 and 2 into stable and unstable was applied to patients with long standing heart block who had previous E.C.G.s. Group 3 patients had an unstable rhythm by definition. Those with atrial fibrillation, flutter, or tachycardia were excluded unless the ventricular rate was less than 56 per minute in the absence of therapy with digoxin or similar drugs. Such cases were classified as complete block if the $R-R$ interval was constant at rest. Otherwise they were considered to have partial block (Stock, 1969).

\section{Results}

Replies were obtained from 282 of the 290 family doctors (Table I): 181 answered the first circular, 76 the second, and 25

TABLE I.-Returns from Circulars to Family Doctor No. of family doctors in the survey area No. of family doctors replying

No. of patients notified by family doctor

No. of additional patients known to the cardiac department

No. of patients with some conduction disturbance

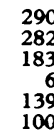

the third. Of the 183 patients notified 139 had some disturbance of atrioventricular conduction and 100 fulfilled the criteria of the study. Of 28 patients with heart block who fulfilled the criteria of the study and who were known to be attending the outpatient department 22 were subsequently notified by their family doctors. The proportion of notified cases in the replies to the first, second, and third circulars is given in Table II.

At the time of the study 76 of the 100 patients had complete heart block, 18 had partial block, and in 6 conduction had returned to normal (Table III). One or more previous E.C.G.s were available in 79 of the patients, two or more in 53, and three or more in 33. The average separation in time between the first and last E.C.G. was 47 months, the maximum being
452 months and the minimum 1 month. In group 1 patients the earlier traces showed partial block in 14 out of 56 . In group 2 patients complete block had been present in 9 out of 17. By definition, partial or complete block had been present

TABLE II.-Numbers of Replies to the First, Second, and Third Circulars and Proportion of Patients Notified who Fulfilled the Criteria of the Heart Block Survey. Six Family Doctors who did not Reply to the First Two Circulars were not Sent a Third

\begin{tabular}{|c|c|c|c|}
\hline & 1st Circular & 2nd Circular & 3rd Circular \\
\hline $\begin{array}{llll}\begin{array}{l}\text { No. sent out } \\
\text { No. replying }\end{array} & \ldots & \ldots & \ldots \\
\text { No. notifying patients } & \cdots & \ldots \\
\text { No. notifying patients } & \begin{array}{l}\text { fulfilling } \\
\text { criteria of study }\end{array} & \ldots & \ldots\end{array}$ & $\begin{array}{l}290 \\
181 \\
76-41 \% \\
57-31 \%\end{array}$ & $\begin{array}{c}109 \\
76 \\
28-36 \% \\
14-18 \%\end{array}$ & $\begin{array}{l}27 \\
25-60 \% \\
7-28 \%\end{array}$ \\
\hline
\end{tabular}

TABLE III.-Classification of Degree and Stability of Block in Patients in the Survey

\begin{tabular}{|c|c|c|c|c|}
\hline Group & $\begin{array}{l}\text { No. of } \\
\text { Patients }\end{array}$ & $\begin{array}{c}\text { No. with } \\
\text { Previous E.C.G.s }\end{array}$ & Stable & Unstable \\
\hline $\begin{array}{l}\text { 1. Complete Block } \\
\text { 2. Partial Block.. } \\
\text { 3. Normal Conduction }\end{array}$ & $\begin{array}{r}76 \\
18 \\
6\end{array}$ & $\begin{array}{r}56 \\
17 \\
6\end{array}$ & $\begin{array}{r}42 \\
8 \\
0\end{array}$ & $\begin{array}{r}14 \\
9 \\
6\end{array}$ \\
\hline Total & 100 & 79 & 50 & 29 \\
\hline
\end{tabular}

in earlier E.C.G.s in all patients in group 3 (one had had partial and five had had complete block). Thus 90 of the patients were known to have had complete block at some time.

Eleven cases of partial or complete heart block were recorded in the Exeter Morbidity Survey 1966-7, implying a prevalence of 16.0 per 100,000 . The data obtained in the Devon County Survey gave a similar value for prevalencenamely, 17.3 per 100,000 , assuming that the population of the area was 581,000 . The prevalence of patients who have had evidence of complete block is 15.5 per 100,000 and that for those with complete block at the time of the survey was 13.1 per 100,000 .

The age range of patients with block was wide-from 3 to 92 years-but most patients were elderly and half were within the range 70 to 85 years. The proportion of cases of partial block is unrelated to age (Table IV). The relation of frequency of block to increasing age is even more obvious when allowance is made for the numbers of subjects at risk in each age group (Table V). Thus the prevalence at age under 40 is 2.5

TABle IV.-Number of Patients with Complete and Partial Heart Block in Different Age Groups

\begin{tabular}{|c|c|c|c|c|c|c|c|}
\hline & & & & & & of Patie & \\
\hline & & Age & & & Complete & Partial* & Total \\
\hline $\begin{array}{r}0-19 \\
20-39 \\
40-49 \\
50-59 \\
60-69 \\
70-79 \\
80-89 \\
90+\end{array}$ & $\begin{array}{l}\ldots \\
\because \\
\because \\
\because \\
\therefore \\
\therefore\end{array}$ & $\begin{array}{l}\cdots \\
\cdots \\
\cdots \\
\cdots \\
\cdots \\
\cdots\end{array}$ & $\begin{array}{l}\cdots \\
\cdots \\
\cdots \\
\cdots \\
\cdots\end{array}$ & $\begin{array}{l}. \\
\cdots \\
\cdots \\
\cdots \\
\cdots \\
\cdots\end{array}$ & $\begin{array}{r}3 \\
3 \\
3 \\
4 \\
19 \\
25 \\
18 \\
1\end{array}$ & $\begin{array}{l}0 \\
1 \\
3 \\
2 \\
5 \\
6 \\
6 \\
1\end{array}$ & $\begin{array}{r}3 \\
4 \\
6 \\
6 \\
24 \\
31 \\
24 \\
2\end{array}$ \\
\hline & & & & & 76 & 24 & 100 \\
\hline
\end{tabular}

* Includes groups 2 and 3.

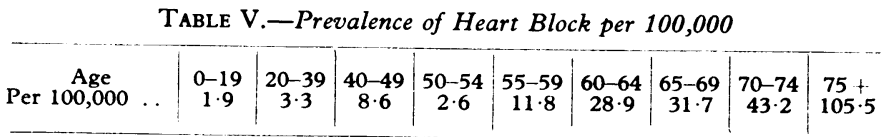

per 100,000 , whereas at over 74 it is 105.5 per 100,000 . Heart block was commoner in men than in women in a ratio of 1.4 to 1 . Since there were fewer elderly men than women in the population at risk the the difference in prevalence of block 
between the two sexes was more pronounced, the male to female ratio being 1.7 to 1 , while above the age of 74 the ratio was 2.3 to 1 .

Most patients with heart block had no evidence of associated cardiovascular disease. Thirteen gave a history of myocardial infarction or had diagnostic cardiographic changes of infarction (W.H.O. criteria). Eleven patients had a previous history of rheumatic fever, six of them having clinical evidence of rheumatic valvular disease. Eight gave a history suggestive of heart block since childhood. Of these one had developed block following surgical repair of a ventricular septal defect; the other seven were presumed to be suffering from congenital heart block though only one had evidence of associated congenital heart disease. One patient had had traumatic pericarditis, and twelve diphtheria in childhood.

The patients' symptoms are presented in Table VI. Of 71 patients who had experienced disturbance of consciousness 48 had lost consciousnesss and were thought to have had

TABLE VI.-Numbers of Patients with Major Symptoms and Evidence of Cardiac Failure in the Different Age Groups

\begin{tabular}{|c|c|c|c|c|c|}
\hline Age in Years & $\begin{array}{c}\text { No. of } \\
\text { Patients }\end{array}$ & $\begin{array}{c}\text { No. with } \\
\text { Adams-Stokes } \\
\text { Attacks }\end{array}$ & $\begin{array}{c}\text { No. with } \\
\text { Dizzy Attacks }\end{array}$ & $\begin{array}{c}\text { No. with } \\
\text { Angina }\end{array}$ & $\begin{array}{c}\text { No. with } \\
\text { Congestive } \\
\text { Cardiac } \\
\text { Failure }\end{array}$ \\
\hline $\begin{array}{ll}\text { Under } 60 & \ldots \\
60-64 & \ldots \\
65-69 & \ldots \\
70-74 & \ldots \\
75-79 & \ldots \\
80-84 & \ldots \\
85 \text { or over } & .\end{array}$ & $\begin{array}{r}19 \\
12 \\
12 \\
13 \\
18 \\
17 \\
9\end{array}$ & $\begin{array}{l}6 \\
7 \\
6 \\
9 \\
9 \\
8 \\
3\end{array}$ & $\begin{array}{l}5 \\
5 \\
5 \\
5 \\
6 \\
6 \\
3\end{array}$ & $\begin{array}{l}5 \\
5 \\
3 \\
1 \\
3 \\
0 \\
1\end{array}$ & $\begin{array}{l}0 \\
2 \\
0 \\
2 \\
2 \\
1 \\
2\end{array}$ \\
\hline Total .. & 100 & 48 & 35 & 18 & 9 \\
\hline
\end{tabular}

Adams-Stokes attacks and 23 had transient episodes of faintness or dizziness but without complete loss of consciousness, while 12 had experienced both types of attack. In most instances these symptoms were particularly troublesome at the onset of the heart block. Indeed only 13 patients had had syncopal attacks within the previous three months. Eighteen patients complained of angina of effort within the preceding three months; 68 had suffered breathlessness on exertion; and 30 complained of ankle swelling within the previous three months. Syncopal attacks tended to be least common at the two extremes of the age range, but in general the frequency of symptoms and signs was similar in the different age groups.

The salient cardiovascular signs are given in Table VII. The mean resting pulse rate in patients with complete block was

\begin{tabular}{|c|c|c|c|c|c|c|c|c|c|}
\hline \multirow[b]{2}{*}{ Group } & \multicolumn{3}{|c|}{$\begin{array}{c}\text { Pulse } \\
\text { per minute }\end{array}$} & \multicolumn{3}{|c|}{$\underset{(\mathrm{mm} . \mathrm{Hg})}{\text { Systolic B.P. }}$} & \multicolumn{3}{|c|}{$\begin{array}{l}\text { Diastolic B.P. } \\
(\mathrm{mm} . \mathrm{Hg})\end{array}$} \\
\hline & Range & $\overline{\text { Mean }}$ & Median & Range & $\overline{\text { Mean }}$ & Median & Range & Mean & $\overline{\text { Median }}$ \\
\hline $\begin{array}{l}1 \\
2 \\
3\end{array}$ & \begin{tabular}{|l|}
$24-80$ \\
$36-88$ \\
$46-112$
\end{tabular} & $\begin{array}{l}45 \cdot 5 \\
55 \\
76 \cdot 3\end{array}$ & $\begin{array}{l}41 \\
50 \\
75\end{array}$ & \begin{tabular}{|l|}
$100-300$ \\
$115-270$ \\
$130-200$
\end{tabular} & $\begin{array}{l}182 \cdot 6 \\
184 \cdot 7 \\
172\end{array}$ & $\begin{array}{l}180 \\
180 \\
180\end{array}$ & $\begin{array}{l}40-170 \\
60-110 \\
60-120\end{array}$ & \begin{tabular}{|l|}
$81 \cdot 7$ \\
$83 \cdot 8$ \\
86
\end{tabular} & $\begin{array}{l}80 \\
80 \\
75\end{array}$ \\
\hline Total & $24-112$ & 49 & 44 & $100-300$ & 182.4 & 180 & $40-170$ & $82 \cdot 3$ & 80 \\
\hline
\end{tabular}

46 , the range being $24-80$. Only 12 patients had pulse rates of over $56 ; 10$ of these had pacemakers fitted. The mean rates for patients in groups 2 and 3 were 55 and 76 per minute, respectively. The mean rate for patients with a recent history of Adams-Stokes attacks was similar to that of those without (48 and 49, respectively). Nine patients had evidence of congestive cardiac failure (raised jugular venous pressure and oedema) and four of these had complained of ankle-swelling. Twelve patients had had cardiac pacemakers fitted.

Two patients were taking digoxin (in both the drug had been started since the heart block had become established); 28 were on Saventrine (isoprenaline hydrochloride) or ephedrine alone; 27 were taking diuretics, 15 were having Saventrine and a diuretic, and three were on hypotensive drugs. None was taking propranolol.

\section{Discussion}

Inevitably some patients with heart block living within the area of the survey have been omitted, so that the figures regarding prevalence will be an underestimate. Possible sources of error may occur at any one of three stages: (1) patients with heart block may not attend their family doctor, (2) the family doctor may not diagnose the conduction disturbance, or (3) the family doctor, having made the diagnosis, may not have notified the patient to the survey.

The largest source of error is likely to occur in the first stage, in that many patients do not complain of symptoms despite heart block. In these instances the condition may be discovered only if some coincidental complaint occurs to make the patient consult his doctor. Analysis of three Exeter practices suggests that $70 \%$ of patients over the age of 59 consult their doctor once or more during a 12 -month period (N. G. Pearson, personal communication, 1969). If the patient consults him the family doctor may note the slow pulse of complete block, but may well miss the presence of partial heart block, while first-degree block would be undetectable without an E.C.G. Therefore the prevalence figures for complete block are probably more accurate than those for lesser degrees of block. Since a fair proportion of patients vary from partial to complete block any attempt to draw too hard and fast a line between the prevalence of the two conditions is unlikely to be very useful.

Notification of patients known to the family doctors seems to have been fairly complete in that 22 of the 28 patients with records in the cardiac department were reported. Furthermore, the prevalence of heart block deduced from the 1966-7 Morbidity Survey records was similar to that for the County Survey. When the survey was planned it was suggested that those family doctors not replying to the first circular might be less interested in the survey and therefore take less trouble to find and report patients. In practice, however, the proportion of patients with block reported by doctors in reply to the second and third circulars was similar to that reported by those who replied to the first, so that it is likely that the same high order of co-operation was maintained.

Previous estimates of the number of patients with heart block in the general population have been confined to patients with complete block attending hospital. The most thorough study of prevalence of heart block in the community is reported from Malmö in Sweden (Johansson, 1966). The area had a population of between 220,000 and 250,000 , and all E.C.G.s taken were likely to be seen in one department. From analysis of the E.C.G.s performed between 1951 and 1964 it appeared that there had been 134 patients with constant block and a further 70 with transient block. These patients included 62 with acute myocardial infarction and 14 with digitalis intoxication. If these two groups are excluded, as in the present survey, the prevalence from Johansson's figures for Malmö would be just under 14 per 100,000 . This figure would imply that there should be 81 cases of constant or transient complete heart block in the Devon clinical area with a population of 581,000 . If the probable difference in populations and the very different method of assessing prevalence are taken into consideration, our figure of 90 patients with past or present evidence of complete block is remarkably close. In the survey presented here an attempt was made to study the prevalence and morbidity of heart block in the community as a whole, rather than in the more selected population of hospita! patients. Certainly 29 of the 100 patients with block had never attended hospital either as inpatients or outpatients and so could not have been traced by any system of search based on hospital records, while 21 patients with block had never had an E.C.G. before being seen in this survey and so would have been missed even if Devon had a single E.C.G. service as in Malmö (Johansson, 1966). The estimate presented here for the 
prevalence of transient and stable complete heart block is therefore likely to be more accurate than the estimates of previous workers who derived their data from hospital or cardiac department attendance records.

The patients with heart block seen in this survey tended to have had less severe symptoms or signs of circulatory disturbance than had those recorded in previous reports (Table VIII). Syncopal attacks occurred in less than half of the

TABLE VIII.-Comparison of Frequency of Syncopal Attacks and Cardiac Failure in Patients with Heart Block found in this Survey with that Reported by other Authors

\begin{tabular}{|c|c|c|c|}
\hline Author & Syncopal Attacks & $\begin{array}{l}\text { Congestive } \\
\text { Cardiac Failure }\end{array}$ & No. of Patients \\
\hline $\begin{array}{l}\begin{array}{l}\text { Zoob and Shirley } \\
\text { (1963) Smith } \\
\text { Hanssen }(1949) \\
\text { Johansson }(1966)\end{array} \\
\text { Penton et al. }(1956) \\
\text { Devon Heart Block Survey }\end{array}$ & $\begin{array}{l}\% \\
77 \\
63 \\
63 \\
61 \\
48\end{array}$ & $\begin{array}{l}\% \\
\overline{44} \\
22 * \\
40 \\
9\end{array}$ & $\begin{array}{c}30 \\
66 \\
116 \dagger \\
224 \\
100\end{array}$ \\
\hline
\end{tabular}

*Assessed on 55 survivors only.

tTotal excluding those with myocardial infarction and Digitalis intoxication.

patients in Devon (48\%), whereas Siddons and Sowton (1967) considered $67 \%$ to be the usual frequency, and the authors quoted in Table VI give similar figures, all being within the range of $61-77 \%$. The difference in frequency of cardiac failure tended to be even greater in that only 9 of the 100 survey patients had evidence of this compared with a frequency of $20-44 \%$ found by previous authors (Hanssen, 1949; Penton et al., 1956; Zoob and Shirley Smith, 1963; Johansson, 1966).

It is possible that the differences between the patients of this survey and those of other series are fortuitous, but it is at least as probable that they reflect a true difference between the clinical condition of heart block as it occurs in the population as a whole and that seen in the specially selected group of patients who attend hospital.

The report of the Cardiology Committee of the Royal Col- lege of Physicians (1967) suggested that pacemakers should be fitted in about half of the patients with complete heart block. Current experience in the cardiac department in Exeter has been in line with this report and about $40 \%$ of patients with block referred within the past five years now have permanent pacemakers. In contrast, only 12 of the 100 patients in the present survey had pacemakers. The few fitted would seem to reflect the rather more benign nature of the condition of heart block seen in the survey patients rather than conservatism on the part of their medical advisers, since only 13 not fitted with pacemakers were found to be still suffering from Adams-Stokes attacks. If the figures for morbidity in heart block presented here are representative for the general population they lend support to the present policy of recommending pacemakers in selected patients only, rather than making pacemaking obligatory once heart block has been diagnosed.

We would like to thank the South Western Faculty of the Royal College of General Practitioners and the family doctors in the Exeter clinical area for their help and co-operation, on which this study depended. We are grateful for the support of the other physicians in the Devon clinical area who referred patients and also kindly allowed us to borrow case-notes. We acknowledge the help and advice of Mr. Dennis Gillings and Dr. N. G. Pearson, of the Institute of Biometry and Community Medicine, University of Exeter, in obtaining population data and in interpreting the results. Part of this work was financed by a grant from the Department of Health and Social Security.

\section{REFERENCES}

Ashford, J. R., and Pearson, N. G. (1968). In Computers in the Service of Medicine, edited by G. MacLachlan and R. A. Shegog, vol. 1 p. 175. London, Oxford University Press.

Cardiology Committee of the Royal College of Physicians (1967). Report on Pacemakers for the Royal College of Physicians (1967).

Hanssen, P. (1949). Acta Medica Scandinavica, 136, 112.

Johanssen, B. W. (1966). Acta Medica Scandinavica, Suppl. No. 451. Penton, G. B., Miller, H., and Levine, S. A. (1956). Circulation, 13, 801 Siddons, H., and Sowton, E. (1967). Cardiac Pacemakers. Springfield, Thomas.

Stock, J. P. P. (1969). Diagnosis and Treatment of Cardiac Arrhythmias. London, Butterworths.

Zoob, M., and Smith, S. K. (1963). British Medical fournal, 2, 1149.

\title{
Supervision of Epileptic Patients Taking Phenytoin
}

\author{
F. B. GIBBERD, ${ }^{*}$ M.R.C.P. ; J. F. DUNNE, $\neq \|$ M.B., B.SC. ; A. J. HANDLEY, † M.R.C.P. ; \\ B. L. HAZLEMAN, $\$ M.R.C.P.
}

\begin{abstract}
Summary: Serum phenytoin concentrations in outpatients and inpatients with epilepsy have been contrasted. Individual patients were receiving prescriptions ranging from 100 to $300 \mathrm{mg}$. of sodium phenytoin daily, but the two groups were comparable in respect of dosage, age, and sex distribution. Whereas the mean phenytoin concentration among 14 inpatients was $28 \mu \mathrm{g} . / \mathrm{ml}$. that among 15 outpatients was only $15.7 \mu \mathrm{g} . / \mathrm{ml}$. When the supervision of a further 12 outpatients was changed to include more frequent visits and regular provision of blood samples their mean serum concentration of phenytoin rose from 17.5 to $27.7 \mu \mathrm{g} . / \mathrm{ml}$.
\end{abstract}

The results indicate that failure to follow dosage instructions is a factor of major importance among epileptic patients whose response to treatment is inadequate or erratic.

\section{Introduction}

Patients with epilepsy may be free of symptoms for long periods; their treatment is always prolonged and its success sometimes uncertain, and unwanted effects are common. It would not be surprising if some patients took their drugs erratically, and reports from Scandinavia and North America suggest that a high proportion of epileptic patients take fewer tablets than those prescribed. Buchthal, Svensmark, and

\footnotetext{
* Consultant Physician

† Medical Registrar. Neurological Clinic, Westminster Hospital, London S.W.1. $\ddagger$ Lecturer.

$\$$ Medical Registrar.

Department of Pharmacology and Therapeutics, the London Hospital Medical College, London E.1.
}

II At present Senior Medical Officer, Committee on Safety of Drugs. 